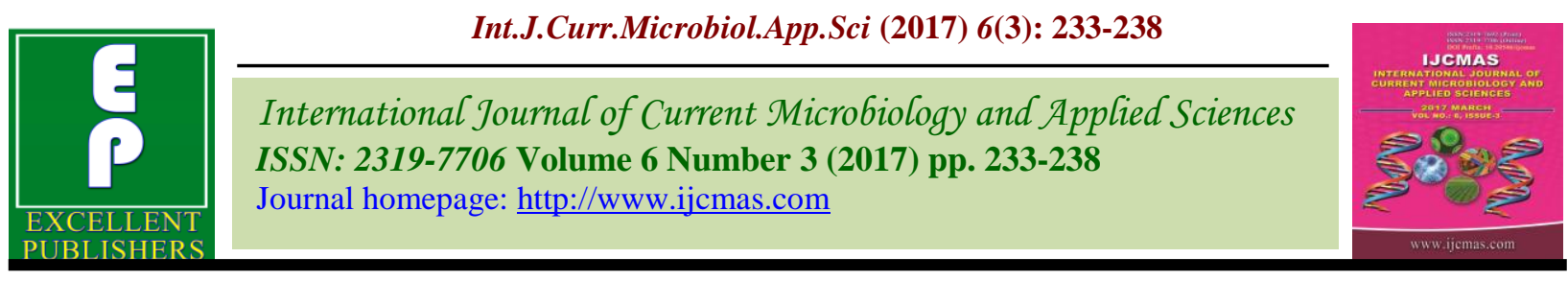

Original Research Article

https://doi.org/10.20546/ijcmas.2017.603.025

\title{
Effect of High Density Planting System (HDPS) and Varieties on Yield, Economics and Quality of Desi Cotton
}

\author{
Pradeep Kumar $^{1,2 *}$, A.S. Karle ${ }^{1}$, Deshraj Singh ${ }^{1}$ and Lalita Verma ${ }^{1}$ \\ ${ }^{1}$ Department of Agronomy, College of Agriculture, VNMKV, Parbhani, \\ Maharashtra - 431402, India \\ ${ }^{2}$ Department of Agronomy, CCS Haryana Agricultural University, Hisar, \\ Haryana - 125004, India \\ *Corresponding author
}

\begin{tabular}{|c|c|}
\hline & A B S T R A C T \\
\hline & \multirow{6}{*}{ 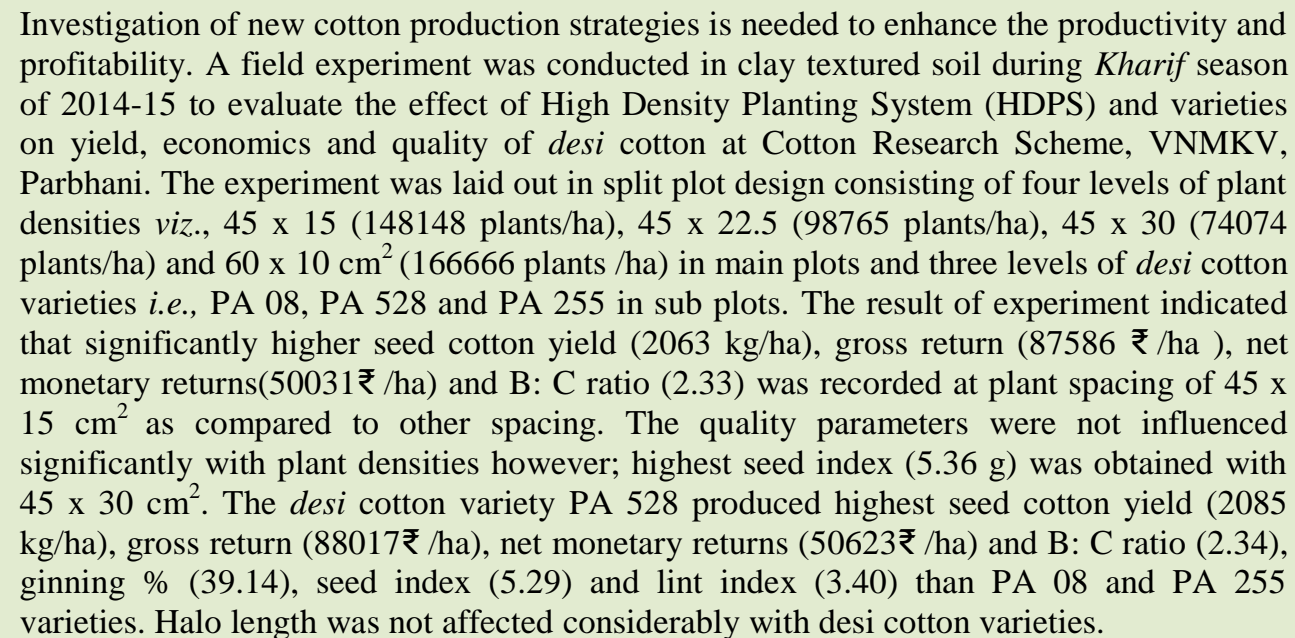 } \\
\hline & \\
\hline $\begin{array}{l}\text { Desi cotton, HDPS, } \\
\text { Economics, Quality, } \\
\text { Varieties, Yield. }\end{array}$ & \\
\hline Article Info & \\
\hline $\begin{array}{l}\text { Accepted: } \\
\text { 08 February } 2017 \\
\text { Available Online: } \\
10 \text { March } 2017\end{array}$ & \\
\hline & \\
\hline
\end{tabular}

\section{Introduction}

Vigilant production and economic strategies are important for cotton growing farmers due to expanding cost of cultivation and stagnating productivity. Adoption of High density Planting System (HDPS) and newly released desi cotton varieties offer an alternate to sustainable production and decrease production cost. Cotton (Gossypium spp.), the queen of fibre or white gold, is one of the most important commercial crop of India. It is one of the most important cash crops next to food grains that play a vital role in Indian national economy (Patel et al., 2016). In India cotton is grown over an area of 115.53 lakh hectares with production of 375.00 lakh bales with productivity of $552 \mathrm{~kg}$ lint/ha (Anonymous, 2014). Cotton production in India is considered to have a wide reaching impact not only on the livelihood of farmers and economy of the country but also on international trade. Even though maximum area is under Bt cotton but 
average productivity is lower than world average. Cotton productivity depends on various factors among them selection of potential genotypes along with plant densities play a vital role in increasing the productivity of cotton. The desi cotton are known to tolerant and resistant to diseases, pests and adverse environmental condition while, American cotton varieties are more susceptible to insect pests like jassids, whiteflies, aphids and diseases bacterial blight, verticillium wilt and leaf curl virus and because of high cost of cultivation they are also considered as major cause of farmer's suicide. New desi cotton genotype viz., PA 08, PA 528have been released in recent times by VNMKV, Parbhani. The maximum exploitation of these genotypes can be achieved only after determining their optimum planting densities in comparison to recommended cotton varieties. In general, it was observed that lower plant densities produces high values of growth and yield attributes per plant, but yield per unit area was higher with higher plant densities (Namdeo et al., 1991; Dhoble et al., 1992; Sharma et al., 2001). However, it may happen that moderate increase in plant densities may not increase the yield but decrease due to competition between plants for nutrients, water, space and light (Nehra and Kumawat, 2003). In view of the above, present research work carried out with the objective to find out the effect of High Density Planting System (HDPS) on yield, economics and quality of desi cotton.

\section{Materials and Methods}

The experiment was conducted at Cotton Research Scheme, VNMKV, Parbhani during 2014-15. The topography of experimental field was fairly uniform, leveled and with a good drainage. The soil was clayey in texture with low in available nitrogen $(157.51 \mathrm{~kg} / \mathrm{ha})$, medium in available phosphorus $(9.68 \mathrm{~kg} / / \mathrm{ha})$ and high in available potassium (466.86 $\mathrm{kg} / \mathrm{ha}$ ). The soil $\mathrm{pH}$, organic carbon and electrical conductivity were $7.86,0.70 \%$ and $0.48 \mathrm{ds} / \mathrm{m}$, respectively. Geographically Parbhani is situated at $19^{\circ} 16^{\prime}$ North latitude and $76^{\circ} 47^{\prime}$ East longitude and at 409 altitude above sea level in Marathwada division encompassed by $17^{\circ} 35^{\prime}$ to $24^{\circ} 40^{\prime}$ ' North latitude and $74^{\circ} 49^{\prime}$ to $78^{\circ} 15^{\prime}$ ' East longitude geographical boundaries. Parbhani comes under subtropical climate. The mean daily maximum and minimum temperatures varies from 29.16 in December to 41.14 in May and 11.95 in December to 24.95 in May, respectively. It has a mean annual precipitation of $963 \mathrm{~mm}$, distributed in 48 rainy days, mostly during June to October. Mean relative humidity ranges from 30 to 90 percent. The experiment was laid out in split plot design with four levels of plant densities i.e. $45 \times 15,45 \times 22.5,45 \times 30$ and $60 \times 10$ $\mathrm{cm}^{2}$ in main plots and three levels of desi cotton varieties i.e., PA 08, PA 528 and PA 255 in sub plots. The crop was sown on $11^{\text {th }}$ July $2014\left(27^{\text {th }} \mathrm{MW}\right)$ by dibbling 2 cotton seeds per hill as per the spacing. The fertilizers were applied as per treatments. Half dose of nitrogen and complete dose of $\mathrm{P}_{2} \mathrm{O}_{5}$ and $\mathrm{K}_{2} \mathrm{O}$ was applied through urea and 10:26:26 fertilizer as basal application. Top dressing of remaining half dose of nitrogen was given after 30 days after sowing through urea by ring method. The plant height was measured in $\mathrm{cm}$ from the base of the plant i.e., ground level to the base of the last fully opened leaf at the apex of plants. The weight of dry matter accumulated in plant is an index of the plant growth. The roots of the plant uprooted for dry matter study, were removed and after removing the roots, the plant were air dried under sun for eight days and subsequently dried in the thermostatic oven at $65 \pm 2^{0} \mathrm{C}$, till they were completely dried. The final constant dry weight was recorded as total dry matter weight in gram per plant. Ginning per cent was calculated treatment wise for second picking (as the yield of seed cotton was more in the second picking) using the following formula: 


\section{Lint weight $(\mathrm{g})$ \\ Ginning per cent $=$---------------------- x 100 \\ Seed cotton weight $(\mathrm{g})$}

The ginning percent alone does not convey any idea about the total production of fibres hence; lint index was calculated to overcome this drawback by using the following formula.

Lint index $=$

Weight of 100 seeds x Ginning (\%)

$$
100 \text { - Ginning (\%) }
$$

Seed index ensures evaluation of types with properly developed seeds and leads to development of lint index. It was worked out by taking weight of 100 seeds ( $g$ ) from each net plot after ginning. Other biometric observations were recorded as per the standard procedure.

\section{Results and Discussion}

Results on yield, economics and quality of desi cotton as influenced by various treatments are presented in table 1.

\section{Growth characteristics}

At harvesting stage, the plant height was maximum $(138.43 \mathrm{~cm})$ when sowing was done at spacing of $60 \times 10 \mathrm{~cm}^{2}$ (Fig. 1). The more number of plants per unit area resulted more height per plant which may be due to the increased competition for sunlight and $\mathrm{CO}_{2}$. Similar type of results was reported by Wankhade et al., (2003); Narayana et al., (2007); Sisodia and Khamparia (2007). The minimum height of crop was recorded with 45 x $30 \mathrm{~cm}$ of plant spacing. Among varieties, PA 528 results significantly highest plant height $(140.74 \mathrm{~cm})$ as compared to other. At harvesting stage, total dry matter accumulation per plant was influenced due to different spacing and it was maximum (78.64 g) in wider plant spacing $45 \times 30 \mathrm{~cm}^{2}$ as compared to $45 \times 22.5,45 \times 15$ and $60 \times 10$ $\mathrm{cm}^{2}$ plant spacing.
The increase in dry matter accumulation per plant at wider spacing mainly due to the larger ground area, maximum moisture, more nutrients and more light interception resulting in more photosynthetic activity and more biomass accumulation through the process of plant metabolism Moola and Giri (2006); Butter and Singh (2007). With respect of varieties maximum dry matter accumulation was observed from PA 528 (76.49 g) than PA 08 and PA 255.

Yield contributing characters, yield and economics

The significantly higher number of picked bolls per plant (15.56) and seed cotton yield per plant $(25.67 \mathrm{~g})$ were under wider plant spacing of $45 \times 30 \mathrm{~cm}^{2}$ due to better development of individual plant in wider plant spacing crop. The widely spaced plant received optimum microclimate and the beneficial influence on plant development. Similar results were observed by Nehra and Chandra (2001). The mean boll weight was not significantly influenced by different plant densities as reported by Moola and Giri (2006).The sowing of cotton at $45 \times 15 \mathrm{~cm}^{2}$ plant spacing produced considerably highest seed cotton yield (2063 kg/ha), the maximum gross monetary return (87586 Rs/ha) and net monetary returns (50031 Rs/ha) and B: C ratio (2.33) as compared to wider spacing due to more number of picked bolls per unit area. At $60 \times 10 \mathrm{~cm}^{2}$ spacing seed cotton yield $(1798 \mathrm{~kg} / \mathrm{ha})$ was decreased because the reduction in yield per plant due to both interplant and intra- plant competition for resources, was more than compensated by increase in the number of plants per unit area. These above are in accordance with those obtained by Giri and Gore (2006); Buttar and Singh (2007); Narayana and Aparna (2011). 
Table.1 Effect of High Density Planting System (HDPS) and varieties on seed cotton yield, economics and quality of desi cotton

\begin{tabular}{|c|c|c|c|c|c|c|c|c|c|c|c|c|}
\hline \multirow[t]{2}{*}{ Treatments } & \multirow{2}{*}{$\begin{array}{c}\text { Picked } \\
\text { bolls } \\
\text { /plant }\end{array}$} & \multirow{2}{*}{$\begin{array}{c}\text { Boll } \\
\text { weight } \\
\text { (g) }\end{array}$} & \multirow{2}{*}{$\begin{array}{c}\text { Yield } \\
\text { (g) } \\
\text { /plant }\end{array}$} & \multirow{2}{*}{$\begin{array}{c}\text { Seed } \\
\text { cotton } \\
\text { yield } \\
(\mathbf{k g} / \mathbf{h a})\end{array}$} & \multicolumn{4}{|c|}{ Economics } & \multicolumn{4}{|c|}{ Quality } \\
\hline & & & & & $\begin{array}{c}\text { Cost of } \\
\text { cultivation } \\
(₹ / h a)\end{array}$ & $\begin{array}{c}\text { Gross } \\
\text { monetary } \\
\text { returns } \\
\text { (₹/ha) }\end{array}$ & $\begin{array}{c}\text { Net } \\
\text { monetary } \\
\text { returns } \\
\text { (₹/ha) }\end{array}$ & $\begin{array}{l}\mathrm{B}: \mathrm{C} \\
\text { ratio }\end{array}$ & $\underset{\%}{\text { Ginning }}$ & $\begin{array}{c}\text { Seed } \\
\text { Index } \\
(\mathrm{g})\end{array}$ & $\begin{array}{c}\text { Lint } \\
\text { Index } \\
(\mathrm{g})\end{array}$ & $\begin{array}{c}\text { Halo } \\
\text { length } \\
(\mathrm{mm})\end{array}$ \\
\hline \multicolumn{13}{|c|}{ Plant densities (plants/ha) } \\
\hline $\begin{array}{l}\begin{array}{l}148148 \\
\left.\mathrm{~cm}^{2}\right)\end{array} \quad(45 \times 15 \\
\end{array}$ & 14.04 & 1.67 & 19.56 & 2063 & 37555 & $\begin{array}{c}8758 \\
6\end{array}$ & 50031 & 2.33 & 37.30 & 5.21 & 3.11 & 22.74 \\
\hline $\begin{array}{l}98765 \quad(45 \times 22.5 \\
\left.\mathrm{cm}^{2}\right)\end{array}$ & 14.67 & 1.84 & 24.33 & 1807 & 35776 & $\begin{array}{c}7603 \\
2\end{array}$ & 40255 & 2.12 & 37.07 & 5.32 & 3.14 & 22.88 \\
\hline $74074\left(45 \times 30 \mathrm{~cm}^{2}\right)$ & 15.56 & 1.90 & 25.67 & 1621 & 34565 & $\begin{array}{c}6790 \\
3\end{array}$ & 33338 & 1.94 & 36.93 & 5.36 & 3.15 & 23.01 \\
\hline $\begin{array}{ll}166666 & (60 \times 10 \\
\left.\mathrm{cm}^{2}\right)\end{array}$ & 10.16 & 1.67 & 14.89 & 1798 & 36431 & $\begin{array}{c}7752 \\
4\end{array}$ & 41093 & 2.12 & 37.77 & 5.03 & 3.06 & 21.79 \\
\hline $\mathrm{SEm} \pm$ & 0.25 & 0.02 & 0.38 & 27.46 & 137 & 1085 & 987 & 0.02 & 0.20 & 0.01 & 0.02 & 0.14 \\
\hline $\mathrm{CD}(P=0.05)$ & 0.86 & NS & 1.32 & 95.05 & 475 & 3754 & 3418 & 0.08 & NS & 0.06 & NS & NS \\
\hline \multicolumn{13}{|l|}{ Varieties } \\
\hline PA 08 & 14.25 & 1.70 & 20.91 & 1803 & 35987 & $\begin{array}{c}7649 \\
8\end{array}$ & 40510 & 2.11 & 34.70 & 5.12 & 2.71 & 22.49 \\
\hline PA 528 & 14.65 & 1.89 & 24.66 & 2085 & 37393 & $\begin{array}{c}8801 \\
7\end{array}$ & 50623 & 2.34 & 39.14 & 5.29 & 3.40 & 22.67 \\
\hline PA 255 & 11.91 & 1.70 & 17.75 & 1579 & 34865 & $\begin{array}{c}6726 \\
9\end{array}$ & 32404 & 1.91 & 37.94 & 5.28 & 3.23 & 22.64 \\
\hline $\mathrm{SEm} \pm$ & 0.09 & 0.01 & 0.29 & 18.11 & 90 & 705 & 615 & 0.01 & 0.05 & 0.01 & 0.01 & 0.17 \\
\hline $\mathrm{CD}(P=0.05)$ & 0.29 & NS & 0.87 & 54.30 & 271 & 2115 & 1844 & 0.04 & 0.16 & 0.03 & 0.03 & NS \\
\hline
\end{tabular}


Fig.1 Plant height and dry matter accumulation of desi cotton as influenced by different plant densities and varieties

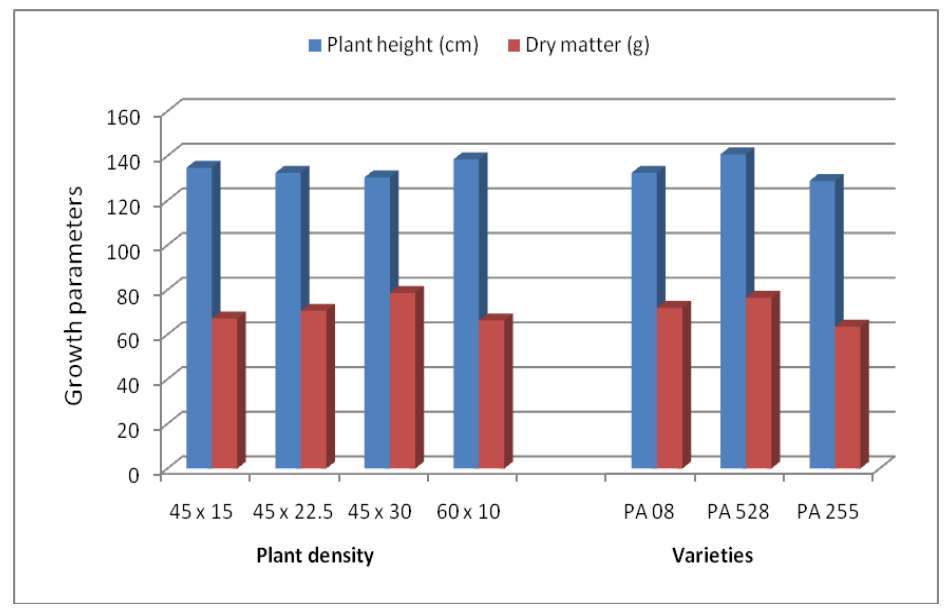

The desi cotton variety PA 528 produced significantly more number of picked boll per plants (14.65), yield per plant (24.66 g), yield per hectare $(2085 \mathrm{~kg})$, gross return (88017₹ /ha), net monetary returns (50623₹ /ha) and B: C ratio (2.34) than PA 08 and PA 255. This might be due to high genetic vigour. However, boll weight and hallo length was not affected significantly due to different desi cotton varieties.

\section{Quality parameters}

The quality characters viz., ginning percentage, lint index, harvest index and halo length were not significantly influenced by various spacing under study. These quality parameters are controlled by genes and nutrition. Since recommended dose of fertilizer was same for all varieties hence variation in quality parameters were not observed significantly. The results are in conformity with those noted earlier by Chabra et al., (1995) and Dhillon et al., (2006). However, seed index was founded significantly higher $(5.36 \mathrm{~g})$ at wider spacing of $45 \times 30 \mathrm{~cm}^{2}$. Similar trend was observed by Dhillon et al., (2006). The desi cotton variety PA 528 produced significantly higher ginning $\%$ (39.14), seed index (5.29) and lint index
(3.40) than PA 08 and PA 255.This might be due to high genetic vigour. However, boll weight and hallo length was not affected significantly due to different desi cotton varieties.

In conclusion, growing desi cotton at plant density of $148148\left(45 \times 15 \mathrm{~cm}^{2}\right)$ provided highest seed cotton yield, gross and net monetary return, $\mathrm{B}$ : $\mathrm{C}$ ratio without significant effect on quality on the other hand, among desi cotton varieties PA 528 provided highest seed cotton yield, gross and net monetary return and $\mathrm{B}$ : $\mathrm{C}$ ratio with high quality parameters excluding halo length.

\section{Acknowledgement}

The author is thankful to Dr. A.S.Jadhav, D.D.R. and In charge of Cotton Research Scheme, Parbhani for providing land, inputs and other facilities required for conducting the above experiment.

\section{References}

Anonymous. 2015. Annual progress report of cotton.www.cab.com.

Buttar, G.S. and Singh, S. 2007. Effect of date of sowing and plant spacing on the 
growth and yield of desi cotton (Gossypiumarboeum L.). J. Cotton Res. Dev., 21(1): 49-50.

Chabra, K.L., Bishnoi, K.C. and Madan, V.K. 1995. Quality of American cotton varieties as affected by plant spacings and nitrogen levels. J. Cotton Res. Dev., 9(2): 121-126.

Dhillon, R.N., Chabra, K.L. and Punia, S.S.2006. Effect of crop geometry and integrated nutrient management on fibre quality and nutrient uptake by cotton crop. J. Cotton Res. Dev., 20(2): 221-223.

Dhoble, M.V., Shaikh, M.Z., Patil, V.D., Giri, D.G. and Pawar, B.R. 1992. Performance of different cotton genotypes as influenced by varying plant row spacings under rainfed conditions. $J$. Cotton Res. Dev., 6(1): 128-134.

Giri, A.N. and Gore, S.B. 2006. Effect of plant densities and NPK levels on yield of newly released desi varieties of cotton. $J$. Cotton. Res. Dev., 20(1): 77-79.

Moola, R. and Giri, A.N. 2006.Response of newly released cotton (Goggypium hirsutum) varieties to plant densities and fertilizer levels. J. Cotton Res. Dev., 20(1): 85-86.

Namdeo, K.N., Sharma, J.K., Choudhary, S.K. and Mandloi, C. 1991. Effect of planting dates and geometry on growth and yield of hirsutum cotton under rainfed condition. J. Cotton Res. and Dev., 5(1): 59-62.

Narayana, E. and Aparna, D. 2011. Performance of cotton varieties (Gossypiumarboreum L.) under different spacings and nitrogen levels in black cotton soils of coastal Andhra Pradesh. J. Cotton Res. Dev.,
25(1): 59-62.

Narayana, E.K. Hema, Srinivasula, K., Prasad, N.V. and Rao, N.H.O. 2007. Agronomic evaluation of $G$. hirsutum hybrid for varied spacing and nitrogen levels in vertisols under rainfed condition. $J$. Cotton Res. Dev., 21(2): 197-200.

Nehra, P.L. and Kumawat, P.D. 2003. Response of hirsutum cotton varieties to spacing and nitrogen levels. J. Cotton Res. Dev., 17(1): 41-42.

Nehra, P.L. and Chandra, M. 2001. Performance of hirsutum cotton under different sowing dates and spacing. $J$. Cotton Res. Dev., 15(2): 147-150.

Patel, P., Patel J.C., Vyas, K.G. and Salvi D. 2016.Effect of hybrids and varying planting time on growth and productivity in cotton (Gossypiumhirsutum L.).The Bioscan, 11(1): 289-291 (Supplement on Agronomy).

Sharma, J.K., Upadhayay, Mishra, U.S., Khamparia, S.K., and Andloi, K.C.M. 2001.Effect of spacing and fertility levels on growth and yield of hirsutum genotypes. J. Cotton Res. Dev., 15(2): 151-153.

Sisodia, R.I. and Khamparia, S.K. 2007. American cotton varieties as influenced by plant densities and fertility levels under rainfed conditions. J. Cotton Res. Dev., 22(1): 35-40.

Wankhade, S.T., Turkhade, A.B., Katkar, R.N., Sakhare, B.A. and Solanke, V.M. 2003. Effect of plant population on growth and yield of cotton hybrids under drip irrigation with mechanical cultivation. $J$. Cotton Res. Dev., 17(2): 142-145.

\section{How to cite this article:}

Pradeep Kumar, A.S. Karle, Deshraj Singh and Lalita Verma. 2017. Effect of High Density Planting System (HDPS) and Varieties on Yield, Economics and Quality of Desi Cotton. Int.J.Curr.Microbiol.App.Sci. 6(3): 233-238. doi: https://doi.org/10.20546/ijcmas.2017.603.025 